\title{
Using blockchain technology to facilitate property transactions
}

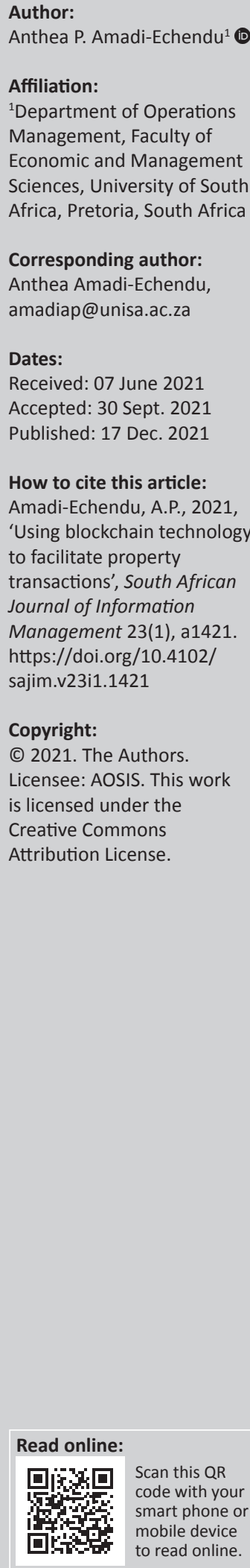

Background: As a medium of exchange, money enables the transfer of economic value and forms the basis of financial transactions. The transition from the third to the fourth industrial revolution has brought about technologies such as blockchain and cryptocurrencies that are transforming monetary transactions and methods of payments.

Objectives: This article discusses an exploratory qualitative study into the use of the blockchain technology to facilitate the processes and payments related to land and landed property administration.

Method: Nineteen semi-structured face-to-face interviews were conducted with role-players who are involved in an authoritative capacity in the current property transfer process.

Findings: The findings show that blockchain technologies could significantly improve the processes involved in maintaining the electronic records associated with landed property. Blockchain technology has only been associated with cryptocurrencies before, and the argument advanced is that fiat currency should be able to be used with the same technology. To maintain the integrity of the property register, the deeds office and the South African Reserve Bank (SARB) must remain in control of the processes. Irrevocable payments should be made against registration confirmation, thus replacing the current paper-based processes with electronic records.

Conclusion: Blockchain technologies can be used with fiat currency and should be considered for ownership tracking of immovable property.

Keywords: blockchain technology; cryptocurrency; distributed ledger; land administration systems; property transactions.

\section{Introduction}

Technological advances provide an impetus to transform and improve land and landed property administration systems, and payment system and processes. Private and governmental stakeholders are involved in property transactions including banks, conveyancers, bridging finance organisations, mortgage originators and estate agents, and all derive payment from property transactions. Payment is the process of transferring money from payer to payee (Kokkola 2010:28), and connects senders and receivers of money (Evans \& Abrantes-Metz 2013:52). Incorrect payments or delays in payments may lead to interest claims which may inflate the overall cost (Sharma 2013:781).

Several countries have updated their property systems to electronically record property transaction information and ownership, but the South African system has remained largely paper based. The paper-based transfer of listed shares was dematerialised in a centralised depository thus removing paper share certificates (Aney \& Banerji 2015:1). The automated process after dematerialisation resulted in a reduced risk of delayed settlement, enhanced profit, a reduction in processing time, financial savings and higher liquidity (Mistry 2013:2). Aney and Banerji (2015:1) added that dematerialisation reduced the opportunities of forgery, theft and loss of paper share certificates. Moreover, process time is reduced because of a real-time electronic endorsement. The capability for dematerialisation has been in operation in South Africa for several years albeit with only the listed shares (Mistry 2013: 1). The same capability can also be used for the trading of other assets. There are various role-players involved in the end-to-end conveyancing process. Figure 1 provides an illustration of the role-players and the arrows provide an indication of the interaction amongst these role-players.

The private sector that deals with property transactions has enabled electronic processes prior to registration to expedite property transactions and link various role players in the end-to-end 


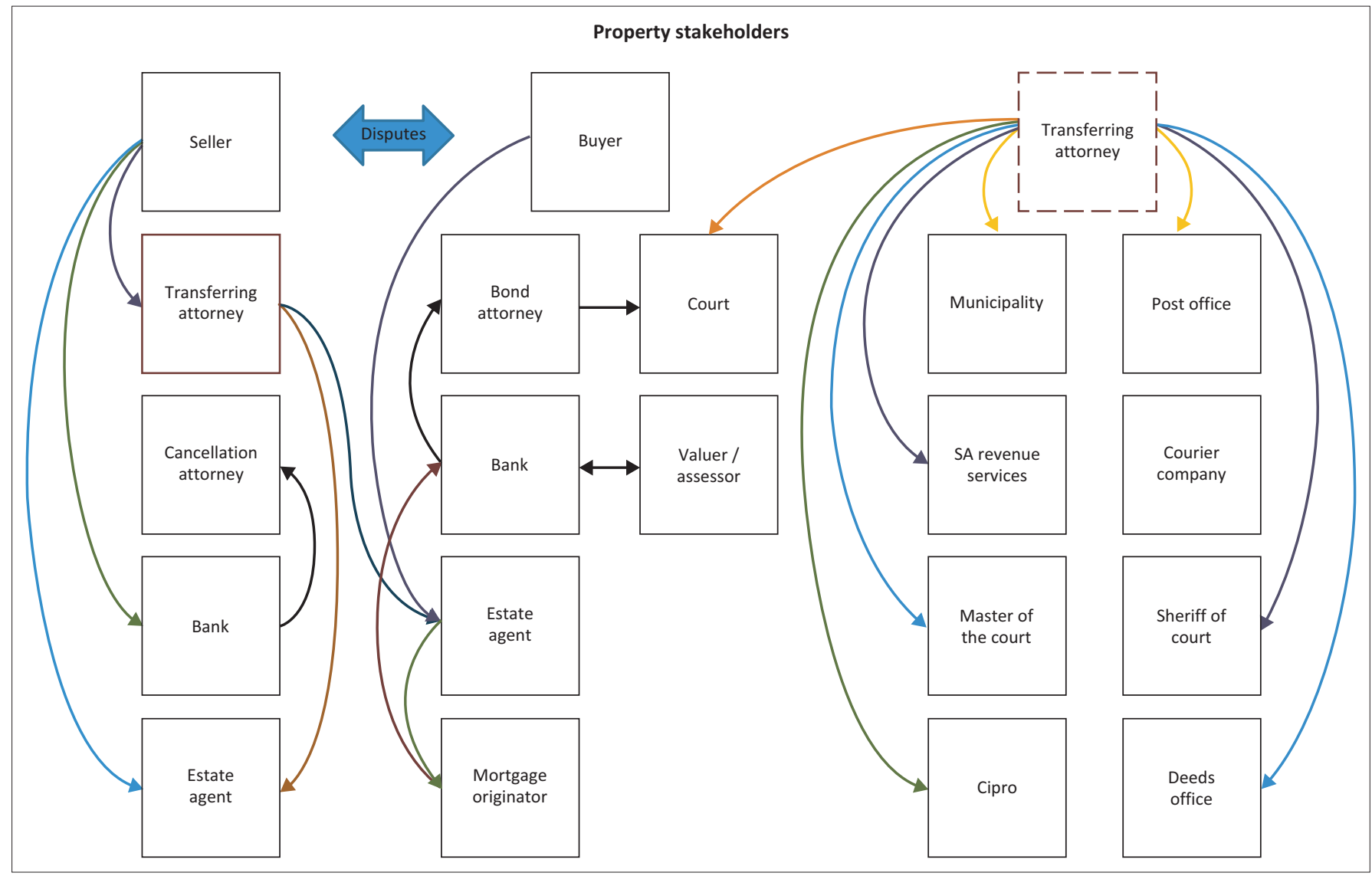

FIGURE 1: Conceptual framework for the South African conveyancing processes.

property. Many organisations had built businesses around these electronic interchanges. In 2009, Parliament debated the architecture for electronic conveyancing but the infrastructure and capability have still not been put into place. Rajashekhar (2006:13) added a payment mechanism to an e-conveyancing system. Incorrect payments may attract interest claims and security breaches lead to fraud and other risks which will need to be mitigated (Fung, Molico \& Stuber 2014:18). In recent times, blockchain technology has emerged as an effective record management system. This article explored the possibility of enhancing the South African property transfer process by introducing blockchain technology to record the ownership of immovable assets. The article builds on the information that was obtained during a doctoral study (Amadi-Echendu 2017).

\section{Literature review}

\section{The current payment process for immovable property transfers}

Payment is the process of transferring monetary value from the buyer to the seller through banks and financial specialists like SWIFT-Society for Worldwide Interbank Financial Telecommunication and SEPA-Single Euro Payments Area (Milkau \& Bott 2015:323, 328). Amazon, Google and PayPal can also do payments but levy higher charges and may thus be unsuitable to administer the multiple payments that form part of property transfers. In South Africa, Bankserv is a national electronic funds transfer (EFT) intermediary that effects interbank clearances (Mamun 2013:9). The Reserve Bank (South African Reserve Bank [SARB]), as central bank, implements policies to regulate the payment industry, and issues bank notes and coins (SARB 2016). Accredited entities interface with the Reserve Bank and must adhere to strict clearing and settlement guidelines (Evans \& Abrantes-Metz 2013:5) to ensure the security and integrity of payment systems.

Banks record digital data of bank deposits and payments (Ali et al. 2014:277) and physical cash do not exchange hands. This is ideal for the implementation of dematerialisation in the property space. Banks must pay on time to avoid interest claims (Soramäki \& Cook 2013:11), but may use intermediaries in a transaction (Craig \& Von Peter 2014:4). Banks borrow from each other, which create interdependencies (Evans \& Abrantes-Metz 2013:52) and increases systemic risk.

Property is often acquired to launder money that was obtained through illegal means. Reliable records must identify parties to transactions to curb money laundering and other illegal activities (Evans \& Abrantes-Metz 2013:17). Paper records can easily be forged, and forgeries are detected by the people who check the documents. Good forgeries may not be detected. A property loan is the most common method of financing new properties. Banks approve buyers based on predetermined credit criteria, but the approval may be based on incorrect or fraudulent information. Interest is charged on loans and is payable in monthly instalments over an agreed period (Itoo, Mutharasu \& Filipe 2014:636). A conveyancer is appointed to 
ensure legal and process compliance in property transactions, and ensure that payments are made to all role-players.

Property payments are revocable, thus increasing the risk attached to property transfers. Modern technologies create new digital platforms that create opportunities to transform financial processes (Ferreira \& Perry 2014:1). However, changing a complex monetary system can have unpredictable and unintentional consequences and these risks should be anticipated and mitigated upfront (Evans \& Abrantes-Metz 2013:53). Different types of payment systems can be explored.

\section{Blockchain technology and virtual payments}

Financial transactions are recorded as digital records (Rosov 2015:37). The blockchain is a 'distributed, shared, encrypted database that serves as an irreversible public repository of information' (Wright \& De Filippi 2015:1). Blockchain technology records transfer information of any asset (DeCovny 2015:24) and the transaction takes place over a network (Twesige 2015:1).

Blockchain technology transacts in real time or within 10 minutes, enable international transactions (Allen 2015:36), is less costly, accessible via the Internet, and publicly available (Twesige 2015:1). Records are openly shared across users in a distributed ledger (Yermack 2015:6, 20). The distributed ledger is decentralised and involves no intermediaries (DeCovny 2015:24). By its nature, therefore, no financial institutions or even the central bank is involved in the peer-to-peer transactions (Peters, Panayi \& Chapelle 2015:5). Central banks can therefore not regulate financial transactions via the blockchain technology without adopting the system.

Encryption keys enhance the security of blockchain transactions by disallowing any tampering of the data (Peters \& Panayi 2015:4). The distributed ledger is a technology that is uniquely capable of performing recordkeeping, monitoring, asset custody, auditing and facilitating trade between parties (Kiviat 2015:585). A single distributed ledger eliminates replication errors by automatically authenticating individual transactions (Allen 2015:6), thereby enhancing the safety of transactions. Information cannot be changed once a transaction is concluded. Blockchain has conventionally been used with cryptocurrencies.

\section{Virtual currency - The future of payment systems?}

Money as a barter tool has changed from gold to coins and printed paper money, and then to digital currency over time (Ali et al. 2014:277). A fiat currency is the currency used by a specific country such as the Rand or Pound. A new innovation of money is digital currencies (Milkau \& Bott 2015:330) that are called cryptocurrencies (McBride 2015:1). Unlike cash, virtual currencies are digitally traded across borders without formal exchange control approval. However, whilst digital interventions are essentially without borders, national and regional boundaries have remained. Cryptocurrencies are in excess of more than 500 different types amounting to an estimated market value of $\$ 4.5$ billion (Peters et al. 2015:15). Bitcoin currency (Moser, Bohme \& Breuker 2013:2) originated as a virtual currency in 2009. It functions independently from the reserve bank (Allen 2015:3; DeCovny 2015:24) and has global reach (Peters et al. 2015:10). The term 'Bitcoin' refers to the entire system and 'bitcoin' refers to the actual currency (Kumar 2013:1).

The Internet revolutionised the distribution and access to information; similarly, Bitcoin could transform payment systems (Cascarilla 2015:19). The scientific principles pertaining to the bitcoin mining process imitate gold (White 2012:414) because there is limited supply (Kiviat 2015:583) as only 21 million bitcoins will be issued. Bitcoin uses pseudonymous identities (Moser et al. 2013:1) which may have contributed to its popularity. Conventional payment systems rely on known identities. The anonymity of Bitcoin role-players has created opportunities for money laundering to occur. Enforcement of the identification of the source of the money transferred through Know your client (KYC) principles (proof of identity and residential address) could detect questionable occurrences (Moser et al. 2013:2). However, enforcing these rules in Bitcoin may be problematic (Peters et al. 2015:12).

Some organisations already trade their products for Bitcoin (DeCovny 2015:24; Twesige 2015:2). The New York State Department of Financial Services allot BitLicences for entities to perform transactions with bitcoins (DeCovny 2015:25; Kiviat 2015:597). Consequently, many major foreign banks abroad have supplemented their legacy systems with digital currency capabilities (DeCovny 2015:25). The Australian government has also acknowledged the existence of bitcoin by publishing Bitcoin tax guidelines (Australian Tax Office 2014:1). However, Russia has legislatively banned the mining and exchange of bitcoins into fiat currency (Reuters 2014:1).

\section{Methodology}

An exploratory study was conducted in the interpretivistic paradigm that used semi-structured qualitative interviews to explore how the property transfer process in South Africa, the case study environment, can be improved. The population were entities that form part of the end-to-end property transfer process in South Africa. To obtain a national view, organisations that represent major entities involved in the end-to-end property process were interviewed and not individual professionals. Purposive sampling was used to identify the participants from the Banking Association, the Master of the High Court, the Law Society of South Africa, the Pretoria deeds office, the surveyor general office, South Africa's Central Securities Depository and central collateral platform (Strate Ltd), Tshwane Municipal Council, and the Reserve Bank of South Africa.

Criteria that had to be complied with included that participants needed to have been employed in a managerial 
position for more than 5 years. Informed consent was obtained from all participants.

Firstly, a desktop literature study was undertaken. There is a general lack of research regarding property related processes in the South African context. Several credible and peer reviewed sources were consulted. Secondly, face-toface semi-structured interviews were conducted with 19 participants involved in the land registration process in South Africa. The interviews were recorded as an unbiased record of the discussions, thus enhancing the credibility of the study. The interviews were transcribed verbatim and pseudonyms were given to each participant. All identifying information have been removed.

Analysis began directly after completing the first interview (Burnard et al. 2008; Maxwell 2008) to guide subsequent interviews (Corbin \& Strauss 1990; Thorne 2000). The interviewer took additional notes during each interview (Doody \& Noonan 2013) that were later used to complement the coded data. The transcribed data were analysed by using content analysis. Literature were verified against the interview data. Subthemes were identified which were clustered into main themes. The interpreted information was sent to the participants to validate the interpretations, thus improving the trustworthiness of the research.

\section{Ethical considerations}

Ethical clearance was obtained from the Department of Records Management in the Faculty of Built Environment at the University of Pretoria as part of a doctoral study.

\section{Results}

The findings are reported based on 19 semi-structured faceto-face interviews that were conducted with stakeholders who are involved in the South African property process, literature that was reviewed, and legislation and documents that were collected during the data collection process. The extracts that relate to the blockchain and distributed ledger from the interviews that were conducted are reflected below. Not all the participants were able to contribute to this topic as not all of the role players are involved with payment instruments. For example, property surveyors that provide valuations of properties did not have knowledge pertaining to irrevocable payments and the blockchain technology.

Michael indicated issues that deal with legislative amendments, strategies to mitigate risk and fraud, and adapting the current structure to make provision for blockchain technology as a trusted recordkeeping system:

'There're umpteen legal acts that need to be changed to facilitate electronic deeds registry, replacing a title deed with an electronic record ... it's more about mitigating the risks, it's more about reducing the fraud that is currently taking place in the industry... what this blockchain technology is proposing. It's just how long it takes to get there and how quickly it can be done.'
George highlighted that blockchain technology and distributed ledgers can record and verify ownership, and the property transfer:

'Companies are looking at the blockchain technology and distributed ledgers, using distributed ledgers, and using the blockchain technology to [...] handle the transfer of ownership of assets. Property transfers, I think, is the type of [...] asset that would be one of the target areas or the areas where people will spend some energy to say can't we actually have this deed of property done in distributed ledgers where we can prove who's the owner and [...] that transfer has taken place. If you talk about disruptive technologies going forward, something like in the property market, I think with the blockchain technology and distributed ledgers I think will probably ... can be a focus area.'

Wendy confirmed that blockchain technology can manage title deeds. She clarified that Bitcoin, a cryptocurrency, is different from blockchain technology and that Rand (the South African fiat currency) can be used instead. The ledger would record the history of every property that is recorded therein:

'If you envisage ... a fully electronic system, I mean, it would be great if they used blockchain technology for example and you have a blockchain for each title deed. You must separate bitcoin, the currency, from blockchain, the technology. Blockchain would ... could work on rand just as easy as. I mean, you don't need to ... you don't have to have blockchain and bitcoin. It ... you can separate the two. So, I'm thinking of blockchain as a technology with rand. So it's not a question of can we accommodate it? It's a technology that will be deployed. When you talk about a distributed ledger, I would imagine you would have a ledger for each property. Like, all the transactions that ever happened to that property would be in that ledger.'

The implication of using the blockchain technology is that the ownership of each property record will be managed in its own ledger as opposed to being updated in a paper-based title deed. Michael stated that authoritative bodies (the South African Revenue Services [SARS] and SARB) would need to acknowledge and allow digital currencies for large-scale trading to commence in South Africa. The central bank does not regulate cryptocurrencies. Also, the custodianship of the property register would need to be concluded. Michael remarked:

'There's a lot of noise in the marketplace about what distributed ledgers and [...] blockchain and cyber currencies and all of these things really are and where their best applications points are. There's no doubt that when you starting to talk about something like this you have to start looking at the ... how the central bank recognises some of these systems, particularly when you're talking about the cyber currencies, the cryptocurrencies. They certainly wouldn't endorse it, they will not endorse something that sees [...] SARS being cut out of it. So, if [...] you and I agree via some cryptocurrency and I give you so many bitcoins for my transaction and SARS never knows about it, well, we've got a problem. One of the questions that one should ask about this [...] blockchain kind of technology is, who owns the register? Who has the right to give effect to changes in a register?'

Michael was of the view that in an e-conveyancing scenario that uses blockchain technology, certain functionalities would 
still need to take place outside the blockchain technology. He opined that the cadastre (up-to-date land information system) would continue to exist and be maintained in parallel with ownership information that may be migrated to blockchain technology:

'I've gotta have a reference to the surveyor-general's (SG) diagrams and say, well, that piece of property identified by the following four corner posts and it's got reference numbers, Global Positioning System (GPS) coordinates. Would I carry that in a blockchain? No, I wouldn't. I'd have a reference number in a blockchain but somewhere along the lines, somebody's gotta have that information to prove that this particular property described as erf 1 Illovo is in fact erf 1 Illovo and it's recognised by the SG as being erf 1 Illovo. There're a number of people who are saying that it can work in the property space. [...] I've yet to see a compelling argument for it. I've yet to see a compelling argument against it. So, time will tell.'

Lester agreed that blockchain technology can be used effectively to keep accurate records. He was not hopeful of introducing the technology into South Africa over the next few years, but articulated the benefits as follows:

'They [National Association of Securities Dealers Automated Quotations - NASDAQ] announced last year July that they're converting to [...] bitcoin technology. Not for the money but for the speed of accuracy of encrypting, decoding and dematerialising transactions. Blockchain ... the transactions are immediate. You have both the money and the transaction and all the detail you can't falsify, and you have a [...] virtually uncrackable transaction record. I just can't imagine that this would be in South Africa in the next ten years. Your title deed, your photograph of the owner, where your transaction details themselves, are all embedded in one electronic record on the [...] cloud or on the Internet not under the control of government or deeds office or anyone like Apple or Google. It is a proprietary system that you buy from NASDAQ, and those people and I know Bloomberg [delivers business and markets news, data and analysis to the world] is planning on commercialising it. If you go with the blockchain route, it is brilliantly fast in certain aspects; in other aspects very slow, but does not foresee its implementation in South Africa, especially not in the near future.'

Jerry emphasised the importance of irrevocable payments that must be made as soon as confirmation of the registration has been received:

'Property transfers would be another case in point where you'd have the ability to uniquely register the ownership of an asset in a far more efficient way than it is today... your central register is validated before the documents [...] even get there you're actually taking away a whole chunk of time. I don't need to validate and vet that the ID number's right because it's already been validated and vetted from where? From the source. From Home Affairs. Deeds Registry has been working on a project for a number of years now on what they call their electronic registry, which was, and probably is [...] really just scanning your paper document into a Portable Document Format (PDF) format type thing. That is not an electronic registry upfront. What they talking about is not changing the way things work. The deeds office needs to be able to issue a confirmation that a transaction has taken place that the property has registered. That confirmation needs to be irrevocable ... On the strength of that irrevocable confirmation payment needs to happen irrevocably...What we're talking about here is something that you could, in theory, cut and paste to anywhere in the world.'

By implication, the technology which is used need to provide access to all parties to enhance transparency, reduce duplicate verifications and capturing of information, and secure trusted payments in an automated process. Also, the requirement is not for the digitisation of the property process by converting paper information to electronic information through scanning, but the electronic and digital integration of data and verifications in a largely automated system.

All the participants who spoke about blockchain technologies (there were 10) were of the view that blockchain technology would add tremendous value to the property process in South Africa and revolutionise the payment industry with digital contracts that do not require people's input (Peters \& Panayi 2015:2). Smart contracts can automate the payments process thus restructuring the entire process (Warren et al. 2019). Blockchain is an ideal technology to manage contractual relationships and value exchanges (Carson et al. 2018). President Ramaphosa signed the Electronic Deeds Registration Systems Bill into law on 02 October 2019 to implement a South African electronic deeds registration system. The architectural design is yet to be made known.

\section{Theoretical underpinning}

Creating value for owners of properties is a shared responsibility amongst the organisations who are involved in property transfers as various role-players contribute different components towards the end-to-end property process. The general systems theory (Chicksand et al. 2012:465) perceives phenomena as a web of relationships (systems) with common behaviours, patterns, properties, views, processes and outputs. A holistic view should be adopted whereby the inputs (information, processes, finance and systems) of all role players (banks, conveyancers, central bank, deeds office, etc.) culminates into one output (the property registration), thus achieving cross-functional efficiencies and effectiveness.

The integration of the supply chain partners into a centralised repository where records are shared in a secure environment, and in which each transaction is managed as a single system as per the systems theory (Halldorsson et al. 2007:291) is the biggest contribution of the study. Systems thinking necessitates constant communication and integration across all role players whereby occurrences in one system (e.g. the introduction of irrevocable payments) affects other systems (e.g. the legislative requirements) that should be managed as one system.

\section{Discussion}

Traditionally banks, especially the central bank has been at the heart of all financial transactions in South Africa. In the current process, the transferring attorney instructs the bank to effect certain payments against pre-issued guarantees. Payments are revocable and can therefore be reversed which 
challenges the payment security. The fundamental concept of dematerialisation is that ownership deems to be transferred the moment the payment has been made for the asset, the socalled 'payment versus delivery' concept. Irrevocable payment made via trusted parties is crucial to protect property ownership rights.

The blockchain technology on the other hand, has largely been used for the mining of cryptocurrencies and has used the decentralised distributed ledger where transactions cannot be reversed. The technology is also a peer-to-peer process that excludes banks and the central bank. With no one entity being in control of the system, the system is also more resilient to cyber-attacks, although the anonymous nature of transactions on the blockchain could allow criminals to launder money through this system. Blockchain technology as a shared system in a supply chain may help to remove bottlenecks and compel supply chain partners to acquire updated technology to remain part of the supply chain and enhance overall competitiveness (Warren et al. 2019).

Cryptocurrencies can be separated from the blockchain technology. The SARB has shown interest in a national digital currency (e-NCA 2017). Various South African financial industry entities including banks, SARB, the Financial Services Board, the Payments Association of South Africa and Strate successfully processed an asset swap via the blockchain technology in October 2016 as a pilot project (Naidoo 2016). It is uncertain as to which entity need to house these technologies at this point. It is also unclear whether blockchain technologies will be used with fiat or virtual currencies. By allowing the central bank access to the blockchain platform to monitor property transactions, one may argue that another centralised power structure is being created which opposes the distributed ledger notion. The argument may be that the whole point of blockchain technology is to decentralise the ownership process.

The deeds office as a government agency currently oversees and manages the property register as a custodian. They fulfil various steps to ensure that the integrity of the South African property register is kept intact, thus protecting owners' property rights. Discrepancies, irregularities and incorrect information negatively affect the trustworthiness of the property register which may lead to the introduction of title insurance to protect ownership titles (Velencoso \& Luz 2013:173).

Recording information without verification may reduce processing time, but in turn may negatively affect titles and rights of immovable property. When reengineering a property registration system, the security of title with corresponding compliance to legal requirements must be considered (Sandberg 2010:111). Custodianship would still need to vest with the deeds office so that the integrity of the property register may continue.

Cross border transactions in cryptocurrency do not require tax payments and can be detrimental to a country's economy. Taxes payable to municipalities are determined by the valuation of the property and are applied towards infrastructural development and maintenance. Many of the participants pointed out that blockchain technology can be used with fiat currency instead of cryptocurrencies. As demonstrated by the South African pilot in 2016, banks and central banks can be involved in the new process that uses blockchain technologies. Property contributes substantially to the South African economy, it is therefore imperative that the accuracy and security of the property register is kept intact.

\section{Conclusion}

There is a need to move away from paper-based property transactions by using newer technology like the blockchain. The option for blockchain technology to work with fiat currency should be acknowledged. Although legislation has been updated to accommodate electronic and paperless transactions for property registrations in South Africa, not much has changed in this space.

Irrevocable payments should be made on receipt of an irrevocable registration confirmation from the deeds office. This is not currently the case; this article therefore explored the introduction of blockchain technologies into the property sector to integrate the electronic records management with the process of managing payments. Despite the many fears of fraud and money laundering, the technology provides a platform to accurately manage the ownership of individual assets. Blockchain technology may employ local fiat currency instead of cryptocurrencies.

Whilst blockchain technologies decentralise transactions, there is a need to include the central bank and deeds office into the process to ensure that taxes are correctly paid and to keep the integrity of the property register intact. It is recommended that the SARB and the deeds office should remain in control of the blockchain technology, if adopted. The introduction of KYC principles will ensure that transactions are not anonymous, and the proceeds of all funds will be traceable and linked to specific entities. This will result in cost and time benefits for all stakeholders involved in the property process. It is further recommended that an irrevocable payment system should be linked to this technology. Future study may investigate the regulation of cryptocurrencies and the resultant relationship with market forces. The legislative framework would need to be adapted to incorporate dematerialisation and blockchain technology.

\section{Acknowledgements}

The author wishes to acknowledge the helpful suggestions and discussions with Prof. Adeline du Toit as supervisor of her doctoral studies at the University of Pretoria.

\section{Competing interests}

The author declares no completing interest exists. 


\section{Author's contributions}

I declare that I am the sole author of this research article.

\section{Funding information}

This work was supported by the University of South Africa.

\section{Data availability}

Qualitative interviews were conducted. The author is in possession of the recordings and transcripts.

\section{Disclaimer}

The views expressed are those of the author and do not reflect the official policy or position of any affiliated agency of the author, and the publisher.

\section{Reference}

Ali, R., Barrdear, J., Clews, R. \& Southgate, J., 2014, Innovations in payment technologies and the emergence of digital currencies, pp. 263-275, Bank of England Quarterly Bulletin, London.

Allen, H.J., 2015, $\$=€=$ Bitcoin?, Suffolk University Law School Research Paper No. 15-33, SSRN, viewed n.d., from http://ssrn.com/abstract=2645001.

Amadi-Echendu, A.P., 2017, 'Towards a framework for the integration of data and data sources in the automation and dematerialisation of land administration systems' Doctoral dissertation, University of Pretoria, Pretoria.

Aney, M.S. \& Banerji, S., 2015, Forgery, market liquidity, and demat trading: Evidence from the National Stock Exchange in India, viewed n.d., from https://docplayer net/14845235-Forgery-market-liquidity-and-demat-trading-evidence-from-thenational-stock-exchange-in-india.html.

Australian Tax Office, 2014, Tax treatment of crypto-currencies in Australia Specifically bitcoin, viewed n.d., from https://www.ato.gov.au/General/Gen/Taxtreatment-of-crypto-currencies-in-Australia---specifically-bitcoin.

Burnard, P., Gill, P., Stewart, K., Treasure, E. \& Chadwick, B., 2008, 'Analysing and presenting qualitative data', British Dental Journal 204(8), 429-432. https://doi. org/10.1038/sj.bdj.2008.292

Carson, B., Romanelli, G., Walsh, P. \& Zhumaev, A., 2018, Blockchain beyond the hype: What is the strategic business value, McKinsey \& Company, Melbourne, pp.1-13.

Cascarilla, C.G., 2015, 'Bitcoin, blockchain, and the future of financial transactions', CFA Institute Conference Proceedings Quarterly 32(3), 18-24. https://doi. org/10.2469/cp.v32.n3.5

Castellano, G.G., 2015, 'Reforming non-possessory secured transactions laws: A new strategy?', The Modern Law Review 78(4), 611-640. https://doi.org/10.1111/1468 2230.12131

Chicksand, D., Watson, G., Walker, H., Radnor, Z. \& Johnston, R., 2012, 'Theoretical perspectives in purchasing and supply chain management: An analysis of the literature', Supply Chain Management: An International Journal 17(4), 454-472. https://doi.org/10.1108/13598541211246611

Corbin, J.M. \& Strauss, A., 1990, 'Grounded theory research: Procedures, canons, and evaluative criteria', Qualitative Sociology 13(1), 3-21. https://doi.org/10.1007/ BF00988593

Craig, B. \& Von Peter, G., 2014, 'Interbank tiering and money center banks', Journal of Financial Intermediation 23(3), 322-347. https://doi.org/10.1016/j.jfi.2014.02.003

DeCovny, S. 2015, 'Chips off the old blockchain', CFA Institute Magazine 26(6), 24-25. https://doi.org/10.2469/cfm.v26.n6.8

Doody, O. \& Noonan, M., 2013, 'Preparing and conducting interviews to collect data', Nurse Researcher 20(5), 28-32. https://doi.org/10.7748/nr2013.05.20.5.28.e327

E-NCA, 2017, SA to get digital currency?, viewed n.d., from http://www.enca.com/ money/sa-to-get-digital-currency.

Evans, D.S. \& Abrantes-Metz, R.M., 2013, The economics and regulation of the Portuguese retail payments system, SSRN, viewed n.d., from https://doi. org/10.2139/ssrn.2375151.

Ferreira, J. \& Perry, M., 2014, 'Building an alternative social currency: Dematerialising and rematerialising digital money Seoul across media', in proceedings of $\mathrm{HCl}$ Korea 2015, pp. 122-131, Hanbit Media.

Fung, B., Molico, M. \& Stuber, G., 2014, Electronic money and payments: Recent developments and issues, Bank of Canada Discussion Paper, (2014-2), pp. 1-34, Bank of Canada, Ottawa.
Halldorsson, A., Kotzab, H., Mikkola, J.H. \& Skjøtt-Larsen, T., 2007, 'Complementary theories to supply chain management', Supply Chain Management: An International Journal 12(4), 284-296. https://doi.org/10.1108/13598540710759808

Itoo, R.A., Mutharasu, S.A. \& Filipe, J.A., 2014, 'Effect of loan value and collateral on value of mortgage default', International Journal of Latest Trends in Finance and Economic Sciences 3(4), 635-651.

Kiviat, T.I., 2015, 'Beyond Bitcoin: Issues in regulating blockchain transactions', Duke Law Journal 65, 569-608.

Kokkola, T., 2010, The payment system: Payments, securities and derivatives, and the role of the Eurosystem, Frankfurt am Main: ecB, viewed n.d., from https://www. ecb.europa.eu/pub/pdf/other/paymentsystem201009en.pdf.

Kumar, R., 2013, Bitcoin explained in layman's terms, viewed n.d., from http:// profit.ndtv.com/news/your-money/article-bitcoin-explained-in-laymansterms-376029.

Mamun, A.A., 2013, Automated cheque clearing system: Tools and practices in Shahjalal Islami Bank Limited, BRAC Business School, BRAC University, Dhaka.

Maxwell, J.A., 2008, Designing a qualitative study, pp. 214-253, Sage, Los Angeles, CA.

McBride, A.D., 2015, 'The shift towards non-monetary currency and the rise of cryptocurrencies: Incorporating non-monetary measurements to allow a nation to take stock of its well-being', Master's thesis, Harvard Extension School, viewed n.d. from https://dash.harvard.edu/handle/1/24078345.

Milkau, U. \& Bott, J., 2015, 'Digitalisation in payments: From interoperability to centralised models?', Journal of Payments Strategy and Systems 9(3), 321-340.

Mistry, H., 2013, What is dematerialisation of shares?, viewed n.d., from http://www. business-standard.com/article/pf/what-is-dematerialisation-ofshares-113072500477_1.htm

Moser, M., Bohme, R. \& Breuker, D., 2013, 'An inquiry into money laundering tools in the Bitcoin ecosystem', in proceedings of the eCrime Researchers Summit (eCRS), pp. 1-14, IEEE, San Francisco, USA.

Naidoo, P., 2016, SA banks successfully swap asset via blockchain network, viewed n.d., from https://www.moneyweb.co.za/news/tech/sa-banks-successfully-swapasset-via-blockchain-network/.

Peters, G.W. \& Panayi, E., 2015, Understanding modern banking ledgers through blockchain technologies: Future of transaction processing and smart contracts on the internet of money, SSRN, viewed n.d., from http://ssrn.com/abstract=2692487.

Peters, G.W., Panayi, E. \& Chapelle, A., 2015, Trends in crypto-currencies and blockchain technologies: A monetary theory and regulation perspective, SSRN, viewed n.d., from http://ssrn.com/abstract=2646618.

Rajashekhar, P.V., 2006, 'E-conveyancing: Challenges and ambitions', paper presented at the International conference on enhancing land registration and cadastre for economic growth in India, New Delhi.

Reuters/Benoit Tessier, 2014, You can play with your bitcoins, but you can't pay with them: Russia may ban cryptocurrencies by 2015, Russia Today, viewed n.d., from https://www.rt.com/business/187440-bitcoin-ban-russia-cryptocurrency.

Rosov, S., 2015, 'Beyond Bitcoin', CFA Institute Magazine 26(1), 37-37. https://doi. org/10.2469/cfm.v26.n1.12

Sandberg, H., 2010, 'Real estate e-conveyancing: Vision and risks', Information and Communications Technology Law 19(2), 101-114.

Sharma, D., 2013, 'Integrated systems for electronic bill presentment and payment', US Patent Application 13/963, p. 781

Soramäki, K. \& Cook, S., 2013, 'SinkRank: An algorithm for identifying systemically important banks in payment systems', Economics: The Open-Access, OpenAssessment E-Journal 7(28), 1-27. https://doi.org/10.5018/economics-ejournal. ja.2013-28

South African Reserve Bank (SARB), 2016, Mandate, SSRN, viewed n.d., from https:// www.resbank.co.za/en/home/about-us.

Thorne, S., 2000, 'Data analysis in qualitative research', Evidence Based Nursing 3(3), 68-70. https://doi.org/10.1136/ebn.3.3.68

Twesige, R., 2015, Bitcoin: A simple explanation of Bitcoin and Blockchain technology, Munich, GRIN Verlag, viewed n.d., from http://www.grin.com/en/ e-book/286736/bitcoin-a-simple-explanation-of-bitcoin-and-block-chaintechnology.w21802.pdf.

Velencoso, M. \& Luz, M., 2013, 'Transfer of immovable and systems of publicity in the Western world: An economical approach', Journal of Civil Law Studies 6(1), 142-173.

Warren, S., Deshmukh, S., Whitehouse, S., Treat, D., Worley, A., Herzig, J. et al., 2019, 'Building value with blockchain technology: How to evaluate blockchain's benefits', World Economic Forum, viewed n.d., from https://www.weforum.org/ reports/building-value-with-blockchain-technology-how-to-evaluateblockchains-benefits.

White, L.H., 2012, 'Making the transition to a new gold standard', Cato Journal 32(2), 411-421, viewed n.d., from http://ssrn.com/abstract=2244487.

Wright, A. \& De Filippi, P., 2015, Decentralized blockchain technology and the rise of lex cryptographia, SSRN, viewed n.d., from SSRN 2580664.

Yermack, D., 2015, Corporate governance and blockchains (No. w21802), National Bureau of Economic Research, New York, NY, viewed n.d., from http://www.nber.org/papers. 